ISSN 0103-8478

\title{
Behavior of Staphylococcus aureus and autochthone microbiota in fresh sausages added of sodium nitrite and stored under refrigeration
}

\author{
Comportamento de Staphylococcus aureus e microbiota autóctone frente à ação de nitrito de sódio \\ em linguiças frescais estocadas sob refrigeração
}

\author{
Lucyanne Maria Moraes Correia ${ }^{\mathrm{I}}$ Juliano Gonçalves Pereira ${ }^{\mathrm{II}}$ \\ José Paes de Almeida Nogueira Pinto ${ }^{\mathrm{III}}$ Vinicius Cunha Barcellos ${ }^{\mathrm{I}}$ \\ Luciano dos Santos Bersot $^{\mathrm{I}}$
}

\begin{abstract}
Fresh sausages are cured meat products that may be contaminated with Staphylococcus aureus during the manufacturing procedure, which is frequently related with inadequate handling practices. The use of nitrite in meat products has proven efficacy against Clostridium botulinum, and studies indicate that bactericidal action against $\mathbf{S}$. aureus depends on factors that are intrinsic and extrinsic to the product. The objective of the present study was to evaluate the effect of nitrite concentration, and $\mathrm{pH}$ on $\mathbf{S}$. aureus and psychrotrophic autochthone microbiota in fresh sausages stored at different times and temperatures. Fresh sausage were produced at nitrite concentrations 50, 150 and $200 p p m$ and contaminated with $\mathbf{S}$. aureus. The sausages were storage at refrigeration $\left(7\right.$ and $\left.12^{\circ} \mathrm{C}\right)$ and the quantification of $\boldsymbol{S}$. aureus and psychrotrophic microorganisms was carried out on days 0,2, 4, 7, and 10. Results showed that nitrite concentrations and the temperatures used had minimal effect on the multiplication of $\boldsymbol{S}$. aureus and psychrotrophic autochthone microbiota. Final counts depended only on the length of storage: at the end of 10 days, counts were statistically similar in the different groups, showing that temperature and nitrite concentrations used did not control microbial growth effectively. It is suggested that the product should be stored below $7^{\circ} \mathrm{C}$ or at freezing temperatures for greater microbiological stability.
\end{abstract}

Key words: Fresh sausage, nitrite, psychrotrophic, S. aureus, temperature.

\section{RESUMO}

A linguiça frescal é um embutido curado que, devido à manipulação durante as etapas de produção, pode se tornar contaminado com $\boldsymbol{S}$. aureus, patógeno frequentemente relacionado com práticas inadequadas de higiene durante a produção de alimentos. A utilização de nitrito em embutidos tem sua eficácia comprovada contra $\boldsymbol{C}$. botulinum e, para o $\boldsymbol{S}$. aureus, estudos indicam que a ação bactericida depende de fatores extrínsecos e intrínsecos. $O$ objetivo do presente estudo foi avaliar o efeito da concentração de nitrito e do $\mathrm{pH}$ frente à contaminação por $\boldsymbol{S}$. aureus e microbiota autóctone em linguiças frescais estocadas em diferente tempos e temperaturas. Linguiças foram produzidas com concentrações de 50, 150 e 200ppm de nitrito e contaminadas com S. aureus. As linguiças foram armazenadas sob refrigeração $(7 e$ $12^{\circ} \mathrm{C}$ ) e a quantificação de $\mathbf{S}$. aureus e psicrotróficos foi realizada nos dias 0, 2, 4, 7 e 10. Os resultados demonstraram que a influência das concentrações de nitrito e temperaturas utilizadas sobre a multiplicação de S. aureus e da microbiota autóctone foi mínima, sendo dependente apenas do período de estocagem. Entretanto, ao final de dez dias, as contagens foram estatisticamente iguais nos grupos analisados, mostrando que as condições de temperatura $e$ concentrações de nitrito utilizadas não exerceram controle efetivo no desenvolvimento destes micro-organismos. Sugere-se que este produto seja armazenado sob temperaturas inferiores $a 7^{\circ} \mathrm{Cou}$ sob congelamento para maior estabilidade microbiológica.

Palavras-chave: Linguiça frescal, nitritos, psicrotróficos, $\mathbf{S}$. aureus, temperatura.

\section{INTRODUCTION}

In Brazil, fresh sausage is one of the most commonly consumed meat products, once manufacture does not require sophisticated technology, and generates, at the end of the process, a product with great sensory acceptance at attractive prices (TERRA, 1998).

Fresh sausages, as other raw meat products, are great substrates for microbial growth

'Departamento de Ciências Veterinárias. Universidade Federal do Paraná (UFPR), Setor Palotina, Palotina, PR, Brasil

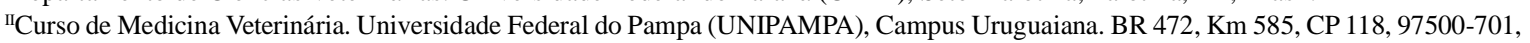
Uruguaiana, RS, Brasil. E-mail: julianopereira@unipampa.edu.br. Autor para correspondência.

"IIDepartamento de Higiene Veterinária e Saúde Pública, Faculdade de Medicina Veterinária e Zootecnia (FMVZ), Universidade Estadual Paulista "Júlio de Mesquita Filho" (UNESP), Botucatu, SP, Brasil. 
due to a series of factors. Among them, high water activity, low acidity, and presence of ingredients that may enable the development of undesirable microorganisms. Besides, as they are intensively handled during manufacture, these products may contain pathogenic microorganisms (SILVA et al., 2004).

Among microorganisms recognized as pathogenic and involved in outbreaks caused by incorrect handling of foodstuffs, S. aureus is widespread and able to survive and multiply in foods when it finds adequate conditions (DO CARMO et al., 2004; JAY, 2005). S. aureus is a saprophytic microorganism that inhabits the skin and nostrils of healthy individuals, giving it an important role in the epidemiological chain of foodborne diseases (DO CARMO et al., 2004; JAY, 2005).

In the USA, in 2008, enterotoxigenic Staphylococci were responsible for $2 \%$ of the outbreaks of bacterial foodborne diseases related with food ingestion, and ranked $6^{\text {th }}$ in terms of occurrence (CDC, 2011). In the European Union, in 2010, Staphylococcus intoxication was responsible for $5.21 \%$ of the total of outbreaks and ranked $4^{\text {th }}$ in occurrence, with pork and pork products as the $5^{\text {th }}$ most important foodstuff involved in outbreaks (EFSA, 2012). In Brazil, data of the Ministry of Health indicate greater epidemiological importance of enterotoxigenic Staphylococcus in the occurrence of outbreaks, ranking second among bacterial pathogens and corresponding to $20.5 \%$ of the total of outbreaks that occur every year (BRASIL, 2013).

After technological processing and during commercialization, fresh sausages are basically preserved by the action of curing salts and low temperatures. The curing salts can be used in fresh sausages at a concentration of $150 \mathrm{ppm}$ (nitrite) and $300 \mathrm{ppm}$ (nitrate) (BRASIL, 1999), but the use of this additive above the limits representing a factor for toxicological risks to human health. Curing salts delay rancidity, inhibit some pathogenic and spoilage microorganisms, and contribute to the development of flavor and color in cured meats (HONIKEL, 2008). Low temperatures delay enzymatic reactions that are vital for microbial development (JAY, 2005).

It is well-known that $\boldsymbol{C}$. botulinum is the main microorganism affected by nitrite and nitrate action in cured foods (SOFOS et al., 1979; TOMPKIN, 2005; DOYLE \& BEUCHAT, 2007), and antimicrobial properties of nitrite were also tested against several other microorganisms, including $\boldsymbol{S}$. aureus (BANG et al., 2008). However, effective concentration against this microorganism depends on parameters that are intrinsic and extrinsic to the product.

Based on these facts, the objective of the present study was to evaluate the effect of temperature of storage time, sodium nitrite concentration, and $\mathrm{pH}$ on enterotoxigenic $\boldsymbol{S}$. aureus and psychrotrophic autochthone microbiota in fresh sausages.

\section{MATERIAL AND METHODS}

Processing of the sausages and sampling method Sausages were processed in the Pilot Plant for Meat Processing at the Veterinary School of Federal University of Paraná (UFPR), Palotina Campus, Paraná, Brazil. Pork jowl and shoulder were ground and mixed for three minutes with the rest of the ingredients $(2 \%$ salt, $0.1 \%$ sugar, $0.2 \%$ garlic paste, $0.05 \%$ black pepper, $0.03 \%$ red pepper, $0.05 \%$ nutmeg, $2.0 \%$ water, and $0.055 \%$ erythorbate). The mixture was divided into three portions of $5.5 \mathrm{~kg}$ each, and placed on trays for the curing salt to be added in final concentrations equal to 50,150 , and $200 \mathrm{ppm}$ of sodium nitrite (treatments A, $\mathrm{B}$, and $\mathrm{C}$, respectively). These procedures were carried out in an adequately sterilized microbiological safety cabinet. After that, trays were kept at $2^{\circ} \mathrm{C}$ for $24 \mathrm{~h}$ for the curing process to completed.

S. aureus inoculum was prepared with six reference enterotoxigenic strains (ATCC 13565, ATCC 14458, ATCC 19095, ATCC 27664, FRI 137, and FRI 361). Each strain, kept in preservation agar, was individually cultured in BHI broth (brain heart infusion) and incubated at $37^{\circ} \mathrm{C} / 24 \mathrm{~h}$. Each culture was streaked on $\mathrm{BHI}$ agar plates and incubated at $37^{\circ} \mathrm{C} / 24 \mathrm{~h}$. One colony was transferred to flasks containing $100 \mathrm{~mL}$ of $\mathrm{BHI}$ broth and incubated at $37^{\circ} \mathrm{C} / 24 \mathrm{~h}$. These subcultures were serially diluted ten-fold up to $10^{-12}$ in $0.9 \%$ saline solution. From each dilution, S. aureus was quantified in BHI pour plates incubated at $37^{\circ} \mathrm{C} / 24 \mathrm{~h}$. This protocol was carried out in order to obtain the 3-log $\mathrm{CFU} \mathrm{g}{ }^{-1}$ inoculum to be used in the study. Immediately before inoculation in the pork mixture, $S$. aureus cultures were mixed in one sterile flask for all the six cultures to be added to the mixture in a single step.

After the curing process, $S$. aureus inoculum with the six strains was uniformly poured on the surface of each of the pork mixtures (treatment A, B, or C), and aseptically homogenized for $5 \mathrm{~min}$. After that, sausages were stuffed, packed, and identified. Groups of three sausage links were packed in polyethylene trays. Two links were used in microbiological analyses, and the other one, to determine $\mathrm{pH}$ of the product. After sausages were

Ciência Rural, v.44, n.10, out, 2014. 
placed on the tray, they were wrapped in PVC, and identified by labels (treatment A, B, or C).

Each treatment were subdivided into two groups that were stored under refrigeration, one at $7^{\circ} \mathrm{C}$ (ideal cooling) and the other at $12^{\circ} \mathrm{C}$ (marginal cooling), in BOD. Sausages were stored for 10 days, and $S$. aureus and psychrotrophic microorganisms were quantified on days $0,2,4,7$, and 10 .

\section{Physical-chemical analyses}

$\mathrm{pH}$

The $\mathrm{pH}$ of the sausages was measured according to official Brazilian methods (BRASIL, 1981).

\section{Microbiological analyses}

The microbiological analyses were carried in Laboratory of Inspection and Quality Control of Food and Water (UFPR).

\section{S. aureus counts}

S. aureus counts were carried out in two sausage links of each treatment (A, B, or C). Links were ground and homogenized in a sterile stomacher plastic bag. From these pooled sample, a $25-\mathrm{g}$ analytical sample was collected and homogenized with $225 \mathrm{~mL}$ of $0.9 \%$ saline solution in a stomacher, producing a $10^{-1}$ dilution. From this dilution, two other were produced, $10^{-2}$ and $10^{-3} . S$. aureus was quantified in Petrifilm STX (3M ), included in the AOAC Official Methods (AOAC, 2000). Analyses were carried out according to the manufacturer's instructions (3M, 2002). Plates were incubated at $35^{\circ} \mathrm{C} / 24 \mathrm{~h}$, and typical colonies were detected by the presence of characteristic purple color (3M, 2002).

Psychrotrophic microorganism counts

Psychrotrophic microorganisms were counted in the dilutions obtained above, cultured in spread plates with plate count agar (PCA). Plates were incubated at $7^{\circ} \mathrm{C} / 10$ days (APHA, 2001).

Statistical analysis

All experiments were carried out in triplicate, and experimental data were submitted to the Analysis of Variance. In order to assess differences between the treatments and variation in counts throughout storage, one-way ANOVA was used $(\mathrm{P} \leq 0.05)$. Student's t-test was used to assess variations between temperatures $(\mathrm{P} \leq 0.05)$. All statistical analyses were carried out in SigmaStat for Windows ${ }^{\circledR}$ 3.0.1, SPSS Inc., Chicago, Illinois, USA (2003).

\section{RESULTS AND DISCUSSION}

Table 1 shows that there was no significant variation $(\mathrm{P} \geq 0.05)$ in $\mathrm{pH}$ throughout storage of the product in two different temperatures and three treatments, demonstrating that there was no interference of $\mathrm{pH}$ in the multiplication of the microorganisms analyzed.

The $\mathrm{pH}$ values recorded during storage at the two temperatures and three treatments ranged from 5.93 to 6.37 , which is the normal $\mathrm{pH}$ of raw, unfermented meat and meat products. This factor may have negatively influenced the action of curing salts on the microorganisms as, according to the ICMSF (ICMSF, 1985), optimum nitrite action occurs between $\mathrm{pH} 5.5$ and 4.5. LUCK \& JAGER (2000) argue that the concentration of curing salts to exert antimicrobial effects on $S$. aureus was lower as the $\mathrm{pH}$ decreased from 7.0 to 4.5 .

In Italy, KAMDEM et al. (2007), found similar results in the evaluation of Tuscan sausage during 14 days of storage, demonstrating small variations in $\mathrm{pH}$, no matter the initial formula, which was probably due to low development of lactic acid bacteria in the product.

Table 1 - Mean $\mathrm{pH}$ of fresh sausages during storage at two different temperatures $\left(7\right.$ and $\left.12^{\circ} \mathrm{C}\right)$ in treatments $\mathrm{A}, \mathrm{B}$, and $\mathrm{C}$.

\begin{tabular}{|c|c|c|c|c|c|c|}
\hline \multirow{2}{*}{ Day } & \multirow[b]{2}{*}{$7^{\circ} \mathrm{C}$} & \multirow[b]{2}{*}{$12^{\circ} \mathrm{C}$} & \multirow[b]{2}{*}{$7^{\circ} \mathrm{C}$} & \multirow[b]{2}{*}{$12^{\circ} \mathrm{C}$} & \multirow[b]{2}{*}{$7^{\circ} \mathrm{C}$} & \multirow[b]{2}{*}{$12^{\circ} \mathrm{C}$} \\
\hline & & & & & & \\
\hline 0 & 6.23 & 6.23 & 6.27 & 6.27 & 6.20 & 6.20 \\
\hline 2 & 6.24 & 6.19 & 6.24 & 6.24 & 6.25 & 6.25 \\
\hline 4 & 5.99 & 6.15 & 6.27 & 6.15 & 6.37 & 6.24 \\
\hline 7 & 6.34 & 6.06 & 6.36 & 6.30 & 6.21 & 6.12 \\
\hline 10 & 6.19 & 6.21 & 6.32 & 5.93 & 6.17 & 5.96 \\
\hline
\end{tabular}

Results are the mean of three analysis per treatment.

* treatments: $\mathrm{A}=50 \mathrm{ppm} ; \mathrm{B}=150 \mathrm{ppm} ; \mathrm{C}=200 \mathrm{ppm}$ 
Table 2 - Mean counts and standard deviation $\left(\log \mathrm{CFU} \mathrm{g}{ }^{-1}\right)$ of $\boldsymbol{S}$. aureus recovered after inoculation and throughout storage at two different temperatures $\left(7\right.$ and $12^{\circ} \mathrm{C}$ ) in fresh sausages submitted to treatments $\mathrm{A}, \mathrm{B}$, or $\mathrm{C}$.

\begin{tabular}{|c|c|c|c|c|c|c|}
\hline \multirow{2}{*}{ Day } & \multirow[b]{2}{*}{$7^{\circ} \mathrm{C}$} & \multirow[b]{2}{*}{$12^{\circ} \mathrm{C}$} & \multirow[b]{2}{*}{$7^{\circ} \mathrm{C}$} & \multirow[b]{2}{*}{$12^{\circ} \mathrm{C}$} & \multirow[b]{2}{*}{$7^{\circ} \mathrm{C}$} & \multirow[b]{2}{*}{$12^{\circ} \mathrm{C}$} \\
\hline & & & & & & \\
\hline 0 & $2.97 \pm 0.5$ & $2.97^{\mathrm{a}} \pm 0.5$ & $3.06 \pm 0.5$ & $3.06^{\mathrm{a}} \pm 0.5$ & $3.03 \pm 0.4$ & $3.03^{\mathrm{a}} \pm 0.4$ \\
\hline 2 & $3.36 \pm 0.3$ & $3.50^{\mathrm{a}} \pm 0.7$ & $3.38 \pm 0.3$ & $3.17^{\mathrm{a}} \pm 0.2$ & $3.40 \pm 0.2$ & $3.42^{\mathrm{a}} \pm 0.3$ \\
\hline 4 & $3.36 \pm 0.3$ & $4.46^{\mathrm{ab}} \pm 0.6$ & $3.40 \pm 0.2$ & $3.93^{\mathrm{ab}} \pm 0.4$ & $4.00 \pm 0.7$ & $3.37^{\mathrm{a}} \pm 0.0$ \\
\hline 7 & $3.87 \pm 0.5$ & $5.75^{\mathrm{b}} \pm 1.7$ & $3.78 \pm 0.3$ & $5.30^{\mathrm{b}} \pm 1.1$ & $3.48 \pm 0.1$ & $4.88^{\mathrm{b}} \pm 0.8$ \\
\hline 10 & $4.66 \pm 1.0$ & $5.71^{\mathrm{b}} \pm 1.3$ & $5.07 \pm 1.3$ & $5.22^{\mathrm{b}} \pm 0.8$ & $4.49 \pm 1.1$ & $5.39^{\mathrm{b}} \pm 0.9$ \\
\hline
\end{tabular}

* Different lowercase letters in the same column are significantly different for $S$. aureus counts $(\mathrm{P} \leq 0.05)$ throughout the study.

** Results are the mean of three analysis per treatment ( \pm standard deviation).

$* * *$ treatments: $A=50 \mathrm{ppm} ; \mathrm{B}=150 \mathrm{ppm} ; \mathrm{C}=200 \mathrm{ppm}$

Table 2 shows the effect of storage temperatures $\left(7\right.$ and $\left.12^{\circ} \mathrm{C}\right)$ and the different treatments (A, B, and C) in the development of S. aureus. At $7^{\circ} \mathrm{C}, S$. aureus counts did not differ statistically $(\mathrm{P} \geq 0.05)$, no matter the treatment. BIRZELE et al. (2005) showed that development of $\boldsymbol{S}$. aureus fresh sausage with different concentrations of nitrite and stored under refrigeration $\left(12^{\circ} \mathrm{C}\right)$ did not differ significantly.

However, keeping sausages at $12^{\circ} \mathrm{C}$ was not enough to control the pathogen, as determined by the comparison of initial (day zero) and final counts (day $10 ; \mathrm{P} \leq 0.05$ ), no matter the treatment.

When the effect of $12^{\circ} \mathrm{C}$ storage is analyzed throughout the study, it was observed that $S$. aureus population inoculated in the product increased significantly $(\mathrm{P} \leq 0.05)$ since the $7^{\text {th }}$ day in the three treatments, and that final populations obtained were statistically similar on the $10^{\text {th }}$ day $(\mathrm{P} \leq 0.05)$, indicating that there was no effect of curing salt concentration on the adaptation of $S$. aureus to the product. According to JAY (2005), there are some observable effects of nitrite on the preservation of cured meats especially when they are vacuum- packed. However, this effect seems to be a result of nitrite action together with other factors of the packaging environment.

S. aureus counts over $5 \log \mathrm{CFU} . \mathrm{g}^{-1}$ were observed in the three treatments at $12^{\circ} \mathrm{C}$ since the $7^{\text {th }}$ day in treatments $\mathrm{A}$ and $\mathrm{B}$, and since the $10^{\text {th }}$ day in treatment $\mathrm{C}$. Counts above this limit may potentially cause foodborne disease due to enterotoxin production (CUNHA NETO et al., 2002; JAY, 2005). Considering that all strains inoculated in the product were enterotoxigenic, it may be said that, if the product was contaminated with an inoculum similar to the one used in this study, the product would pose a public health risk. However, enterotoxin production was not evaluated in the present study.

Other authors reported fresh sausages that were inadequate for consumption due to high Staphylococcus counts. Intensive handling of the product from manufacturing to consumption was considered to be a predisposing factor for the detection of these microorganisms in the samples analyzed (MARQUES et al., 2006).

Table 3 showed mean counts and standard deviations of psychrotrophic counts. In this table,

Table 3 - Mean counts and standard deviation $\left(\log \mathrm{CFU} \mathrm{\textrm {g } ^ { - 1 } )}\right.$ of psychrotrophic microorganisms recovered after inoculation and throughout storage at two different temperatures $\left(7\right.$ and $\left.12^{\circ} \mathrm{C}\right)$ in fresh sausages submitted to treatments $\mathrm{A}, \mathrm{B}$, or $\mathrm{C}$.

\begin{tabular}{|c|c|c|c|c|c|c|}
\hline \multirow{2}{*}{ Day } & \multicolumn{2}{|c|}{-------------------------A } & \multicolumn{2}{|c|}{ - } & \multicolumn{2}{|c|}{ - } \\
\hline & $7^{\circ} \mathrm{C}$ & $12^{\circ} \mathrm{C}$ & $7^{\circ} \mathrm{C}$ & $12^{\circ} \mathrm{C}$ & $7^{\circ} \mathrm{C}$ & $12^{\circ} \mathrm{C}$ \\
\hline 0 & $2.71^{\mathrm{a}} \pm 0.2$ & $2.71^{\mathrm{a}}+0.4$ & $2.81^{\mathrm{a}} \pm 0.1$ & $2.81^{\mathrm{a}}+0.1$ & $2.71^{\mathrm{a}} \pm 0.4$ & $271^{a}+04$ \\
\hline 2 & $4.21^{\mathrm{a}} \pm 0.8$ & $5.97^{\mathrm{b}} \pm 0.5$ & $3.58^{\mathrm{a}} \pm 0.3$ & $4.54^{\mathrm{b}} \pm 0.1$ & $3.10^{\mathrm{a}} \pm 0.5$ & $3.87^{\mathrm{a}} \pm 0.5$ \\
\hline 4 & $6.47^{\mathrm{b}} \pm 0.4$ & $7.67^{\mathrm{c}} \pm 0.2$ & $5.75^{\mathrm{b}} \pm 0.1$ & $7.31^{\mathrm{c}} \pm \pm 0.9$ & $4.53^{\mathrm{a}} \pm 0.1$ & $6.76^{\mathrm{b}} \pm 0.6$ \\
\hline 7 & $7.86^{\mathrm{c}} \pm 0.4$ & $8.57^{\mathrm{c}} \pm 0.8$ & $8.17^{\mathrm{c}} \pm 0.9$ & $8.23^{\mathrm{c}} \pm 0.6$ & $8.03^{b} \pm 1.5$ & $8.09^{c} \pm 0.6$ \\
\hline 10 & $9.50^{\mathrm{c}} \pm 1.3$ & $8.67^{\mathrm{c}} \pm 0.08$ & $9.60^{\mathrm{d}} \pm 1.0$ & $9.99^{\mathrm{c}} \pm 1.6$ & $8.60^{\mathrm{b}} \pm 1.4$ & $9.03^{\mathrm{c}} \pm 0.2$ \\
\hline
\end{tabular}

\footnotetext{
* Different lowercase letters in the same column are not significantly different for psychrotrophic counts $(\mathrm{P} \leq 0.05)$ throughout the study.

** Results are the mean of three analysis per treatment ( \pm standard deviation).

$* * *$ treatments: $\mathrm{A}=50 \mathrm{ppm} ; \mathrm{B}=150 \mathrm{ppm} ; \mathrm{C}=200 \mathrm{ppm}$.
} 
it may be observed that multiplication in this group of microorganisms increased significantly with the temperature, throughout the study. At $7^{\circ} \mathrm{C}$, counts increased significantly $(\mathrm{P} \leq 0.05)$ since the $4^{\text {th }}$ day in treatments $\mathrm{A}$ and $\mathrm{B}$, and since the $7^{\text {th }}$ day in treatment C. At $12^{\circ} \mathrm{C}$, the same phenomenon was observed since the $2^{\text {nd }}$ day in treatments $\mathrm{A}$ and $\mathrm{B}$, and since the $4^{\text {th }}$ day in treatment $\mathrm{C}$. However, on the $10^{\text {th }}$ day of storage, there was no difference in final counts when the different temperatures and treatments were compared, indicating that this group of microorganisms was not controlled by these parameters: psychrotrophic counts showed an almost 6-log increase throughout storage.

Some authors observed inhibition of psychrotrophic counts in sausages formulated with curing salts, an effect that was only observed when $\mathrm{pH}$ of the product was reduced (LUECKE, 1987; SANZ et al., 1997).

\section{CONCLUSION}

The $\mathrm{pH}$ values obtained during storage in the two temperatures and three treatments were constant, and did not affect the multiplication of the microorganisms analyzed.

In the present study, control of S. aureus in fresh sausages was dependent on the temperature of storage, and was not influence by the concentration of curing salt. Temperature abuse during the storage of the product at $12^{\circ} \mathrm{C}$ may pose a risk to the health of the consumer due to counts over $5 \log \mathrm{CFU} \mathrm{g}{ }^{-1}$.

Neither nitrite concentrations used in the manufacture of fresh sausages, nor storage temperatures effectively controlled the development of autochthone psychrotrophic microbiota.

\section{REFERENCES}

AOAC (ASSOCIATION OFFICIAL ANALYTICAL CHEMISTS) - HORWITZ, W. Official methods of analysis of the Association of Official Analytical Chemists. 17.ed. Arlington, 2000. 2200p.

APHA (AMERICAN PUBLIC HEALTH ASSOCIATION). Compendium of methods for the microbiological examination of foods. 4.ed. Washington, 2001. 676p.

BANG, W. et al. Effect of salt and sodium nitrite on growth and enterotoxin production of Staphylococcus aureus during the production of air-dried fresh pork sausage. Journal of Food Protection, v.71, p.191-195, 2008. Available from: <http://www. ncbi.nlm.nih.gov/pubmed/18236683>. Accessed: Ago. 20, 2013.

BIRZELE, B. et al. A study of the role of different nitrite concentrations on human pathogenic bacteria in fresh spreadable ham and onion sausage. Food Control, v.16, p.695-699, 2005. Available from: <http:// www.sciencedirect.com/science/article/pii/S0956713504001252>. Accessed: Out. 16, 2013. doi: 10.1016/j.foodcont.2004.06.006.
BRASIL. MINISTÉRIO DA AGRICULTURA, PECUÁRIA E ABASTECIMENTO. Portaria n.1, de 07 de outubro de 1981. Métodos analíticos para controle de produtos de origem animal e seus ingredientes. Diário Oficial da União, Brasília, DF, 1981.

BRASIL. MINISTÉRIO DA SAÚDE. Portaria n.1004, de 11 de dezembro de 1998, republicada no Diário Oficial da União em 22 de março de 1999. Atribuição de função de aditivos, aditivos e seus limites máximos de uso para a categoria 8 - Carne e produtos cárneos. Diário Oficial da União, Brasília, DF, 1999.

BRASIL. MINISTÉRIO DA SAÚDE. Secretaria de Vigilância em Saúde, Coordenação de Vigilância das Doenças de Transmissão Hídrica e Alimentar. Análise epidemiológica dos surtos de doenças transmitidas por alimentos no Brasil. Available from: <http://portal.saude.gov.br/portal/arquivos/pdf/surtos_dta_15. pdf>. Accessed: Ago. 20, 2013.

CDC CENTERS FOR DISEASE CONTROL AND PREVENTION). U.S. Department of Health and Human Services. MMWR - Morbidity and Mortality Weekly Report, v.60, p.1199, 2011. Available from: <http://www.cdc.gov/mmwr/PDF/ wk/mm6035.pdf $>$. Accessed: Ago. 20, 2013.

CUNHA NETO, A. et al. Staphylococcus enterotoxigênico em alimentos in natura e processados no estado de Pernambuco, Brasil. Ciência e Tecnologia de Alimentos, v.22, p.263-271, 2002. Available from: <http://www.scielo.br/scielo.php?pid=S010120612002000300012\&script=sci_arttext $>$. Accessed: Ago. 20, 2013. doi: 10.1590/S0101-20612002000300012.

DO CARMO, L.S. et al. A case study of a massive staphylococcal food poisoning incident. Food Borne Pathogens and Disease, v.1, p.241-246, 2004. Available from: <http://www.ncbi.nlm.nih. gov/pubmed/15992286>. Accessed: Ago. 20, 2013. doi: 10.1089/ fpd.2004.1.241.

DOYLE, M.P.; BEUCHAT, L.R. Food microbiology: fundamentals and frontiers. 3.ed. Washington: ASM, 2007. 1038p.

EFSA (EUROPEAN FOOD SAFETY AUTHORITY). European Centre for Disease Prevention and Control. The European Union Summary Report on Trends and Sources of Zoonoses, Zoonotic Agents and Food-borne Outbreaks in 2010. EFSA Journal, v.10, p.442, 2012

HONIKEL, K.O. The use and control of nitrate and nitrite for the processing of meat products. Meat Science, v.78, p.6876, 2008. Available from: <http://www.ncbi.nlm.nih.gov/ pubmed/22062097>. Accessed: Ago. 20, 2013. doi: 10.1016/j. meatsci.2007.05.030.

ICMSF (INTERNATIONAL COMMISSION ON MICROBIOLOGICAL SPECIFICATIONS FOR FOODS). Ecología microbiana de los alimentos. II. Productos alimenticios. Zaragoza: Acribia, 1985

JAY, J. Microbiologia de alimentos. 6.ed. Porto Alegre: Artmed, 2005. 711p.

KAMDEM, S. et al. Shelf-life and safety characteristics of Italian Toscana traditional fresh sausage (Salsiccia) combining two commercial ready-touse additives and spices. Food Control, v.18, p.421-429, 2007. Available from: <http://www.sciencedirect.com/ science/article/pii/S0956713505002884>. Accessed: Ago. 23, 2013. doi: 10.1016/j.foodcont.2005.11.013. 
LUECKE, F.K. Microbiological process in the manufacture of dry sausage and raw ham. Fleischwirtschaft, v.66, p.1505-1509, 1987.

LUCK, E.; JAGER, M. Conservacion química de los alimentos. Zaragoza: Acribia, 2000.

MARQUES, S. et al. Avaliação higiênico-sanitária de lingüiças tipo frescal comercializadas nos municípios de Três Corações e Lavras, MG. Ciência e agrotecnologia, v.30, p.1120-1123, 2006. Available from: <http://www.scielo.br/scielo.php?script=sci_artte xt\&pid=S1413-70542006000600012 >. Accessed: Ago. 20, 2013. doi: 10.1590/S1413-70542006000600012.

SANZ, Y. et al. Effect of nitrate and nitrite curing salts on microbial changes and sensory quality of rapid ripened sausages. International Journal of Food Microbiology, v.37, p.225229, 1997. Available from: <http://www.ncbi.nlm.nih.gov/ pubmed/9310859>. Accessed: Ago. 20, 2013. doi: 10.1016/ S0168-1605(97)00060-3.
SILVA, W.P. et al. Listeria spp. no processamento de lingüiça frescal em frigoríficos de Pelotas, RS, Brasil. Ciência Rural, v.34, p.911-916, 2004. Available from: <http://www.scielo. br/scielo.php?pid=S0103-84782004000300039\& script $=$ sci arttext>. Accessed: Ago. 20, 2013. doi: 10.1590/S010384782004000300039 .

SOFOS, J.N. et al. Botulism control by nitrite and sorbate in cured meats: a review. Journal of Food Protection, v.42, p.739-770, 1979 .

TERRA, N.N. Apontamentos de tecnologia de carnes. São Leopoldo: Unisinos, 1998. 216p.

TOMPKIN, R.B. Nitrite. In: DAVIDSON, P.M. et al. (Eds.). Antimicrobials in food. 3.ed. Boca Raton: CRC, Taylor \& Frances Group, 2005. p.169-236.

3M do Brasil LTDA. "3M Petrifilm Staph Express Count System Interpretation Guide.” USA, 2002. 